\title{
Rocco Rante (ed.). Greater Khorasan. History, Geography, Archaeology and Material Culture. Studies in the History and Culture of the Middle East
}

\section{Iván Szántó}

\section{(2) OpenEdition \\ 1 Journals}

\section{Electronic version}

URL: http://journals.openedition.org/abstractairanica/42446

DOI: $10.4000 / a b s t r a c t a i r a n i c a .42446$

ISBN: 1961-960X

ISSN: 1961-960X

Publisher:

CNRS (UMR 7528 Mondes iraniens et indiens), Éditions de l'IFRI

\section{Electronic reference}

Iván Szántó, « Rocco Rante (ed.). Greater Khorasan. History, Geography, Archaeology and Material Culture. Studies in the History and Culture of the Middle East », Abstracta Iranica [Online], Volume 37-38-39 | 2018, document 1, Online since 10 March 2018, connection on 28 September 2020. URL : http://

journals.openedition.org/abstractairanica/42446 ; DOI : https://doi.org/10.4000/abstractairanica. 42446

This text was automatically generated on 28 September 2020.

Tous droits réservés 


\title{
Rocco Rante (ed.). Greater Khorasan. History, Geography, Archaeology and Material Culture. Studies in the History and Culture of the Middle East
}

\author{
Iván Szántó
}

\section{REFERENCES}

Rocco Rante (ed.). Greater Khorasan. History, Geography, Archaeology and Material Culture. Studies in the History and Culture of the Middle East, vol. 29. Berlin \& Munich \& Boston: Walter de Gruyter, 2015, 310 p., ISBN: 978-3-11-033170-7

1 Following a major study by Christine Nölle-Karimi (2014) which posited that historical Khorasan was where Herat was perceived as an imaginary centre, this newest volume about the same region assumes a decentralised approach to the Iranian East. It shows Khorasan to be a multipartite entity made of irrigated arable lands and oases under the dominance of four cities, Nišāpūr, Marv, Herat, and Balkh, and bordered by the Dašt-e Kavīr and Qara Qūm deserts, the Āmū Daryā, and the Hindu Kush range. This introductory delimitation by David Durand-Guédy is further elaborated by Rocco Rante, showing the ambiguity behind the various notions that have been coined to distinguish between "Khorasan proper" and "Greater Khorasan", or "Inner" and "Outer" Khorasan, ultimately revealing the impossibility to outline strict boundaries for this land, which modern political borders were to effectively wipe out by slicing through it. Our sources demonstrate the extreme elasticity of Khorasan which was stretched in some texts as far east as India and as far west as Hamadan.

Strictly speaking, only one article, written by a team of four authors, deals with the pre-Islamic human geography of the region (E. Fouache, H.-P. Francfort, C. Cosandey, Ch. Adle, "La crise d'aridité climatique de la fin du 3ème millénaire av. J.-C., à la lumière 
des contextes géomorphologique de 3 sites d'Iran Oriental (Bam, Tepe Damghani, Jiroft)", pp. 27-38). The essay in question includes two regions-Bam and Jiruft-which have not been historically understood to lie within even a "Greater" Khorasan, as opposed to the Central Khorasan land of Sabzavār, the third target area. This essay is an attempt to demonstrate adaptation strategies of human societies in these East Iranian regions in response to an arid period during the late third millennium BCE, leading to the development of an irrigation system now known as qanāts.

3 The next article represents the transition period between the pre-Islamic and Islamic periods through the example of Nisa, the cradle of the Arsacid Empire (C. Lippolis, V. Messina, "From Parthian to Islamic Nisa", pp. 39-50). It stresses the continuous habitation in New Nisa well into the time of the Caliphate, in contrast to the abandoned former royal seat at Old Nisa. Soviet and Post-Soviet research have shown the eventual repopulation of not only old Nisa during the Seljuq period, but also the area connecting the two citadels, this latter still providing sustenance for a permanent settlement today. It is argued that the building methods and techniques employed for the re-used structures form a bridge between the two major epochs.

4 All the remaining eight studies are dealing with the Islamic period. Paul Wordsworth in his article about $10^{\text {th }}-13^{\text {th }}$-century Marv positions the oasis at the crossroads of East Khorasan through corroborating previous research (YuTAKE, AMP) with satellite image anomalies, to sharpen our view of the Great Khorasan Road and its stations, for instance Dandanaqan ("Merv on Khorasanian trade routes from the $10^{\text {th }}-14^{\text {th }}$ centuries", pp.51-62). Ute Franke's detailed essay provides a reassessment of PreTimurid Herat, giving an outline of its political history and modern archaeological investigations, before presenting new results which emerged from Post-War explorations (2004-2012) ("Ancient Heart Revisited. New Data from Recent Archaeological Fieldwork", pp. 63-88). A major theme in the discussion is the location of certain frequently mentioned yet elusive sites, such as Fošanj, in the historical topography of Herat. Excavations inside the city, at the Qohandez and the Qala-ye Ekhtiyār al-Dīn, aimed to recover traces of Alexander's ancient city and the places mentioned in Islamic sources. While prehistoric occupation was attested for the first time due to these excavations, the Hellenistic city could not be located, and current evidence points to the assumption that the nucleus of present-day Herat (the famous square city) dates to the Sasanian period. Another major essay, by Chahryar Adle, investigates three early Islamic mosques from Greater Khorasan, notably Bastām, Balkh, and Zowzān ("Trois mosquées du début de l'ère islamique du Grand Khorassan", pp. 89-114). Although neither of the three follows the classical Persian mosque plan centred around four eyvāns, they do not constitute a single group and the article treats them separately in three sub-chapters loosely bound together.

Nišāpūr is the subject of the four last articles. A three-author essay about its urban topography attributes the repeated relocation of the population to major military and seismological events, attempting to link the shifting settlement pattern with these upheavals and relying on both recent archaeological fieldworks and remote imagery analysis (H. Laleh, A. Mokarramifar, Z. Lorzadeh, "Le paysage urbain de Nishapur", pp.115-124). Annabelle Collinet reports about the ceramic finds excavated at the šahrestān area of Nišāpūr by the French-Iranian archaeological mission of 2007 ("Nouvelles recherches sur la céramique de Nishapur: la prospection du shahrestan", pp. 125-140). Most of the 1000 sherds are locally made and datable between the $8^{\text {th }}$ and 
the $12^{\text {th }}$ centuries, implying that this area and the Qohandez above it are coeval. The next study, by Marika Sardar ("Archaeological Material in the Museum Setting", pp. 141-150), considers the archaeological material recovered from Nī̌sāpūr in a historiographical perspective, as reflected by the exhibition history of the finds in the Metropolitan Museum, New York, while the following essay, by Vicki Parry, examines the same material in the light of the restorations it has undergone in the past 70 years (Nishapur Ceramics in the Metropolitan Museum of Art", pp.151-160). The closing, multi-author article ("Le Grand Khorasan: Datation par des méthodes physicochimiques [carbone 14 et luminescence]") revisits Nī̌āpūr, Paykend, and other Khorasanian sites, to precise the dating of local finds using state-of-the-art interdisciplinary methods.

\section{AUTHORS}

\section{IVÁN SZÁNTÓ}

Eötvös Loránd University, Budapest \& Austrian Academy of Sciences, Vienne 